\title{
Lobbying in US Senate heads off restrictions on foreign researchers
}

Washington. An immigration bill scheduled for debate in the US Senate next week has been amended to remove barriers to hiring non-US citizens that were contained in an earlier draft. The change, announced last week, makes it unlikely that laws regarding employment of legal immigrants including researchers - will be changed substantially this year.

The decision to accept the amendment follows intense lobbying by a coalition of businesses, universities, civil rights groups and other organizations over the past few months against the employment provision in the bill, sponsored by Senator Alan Simpson (Republican, Wyoming).

Simpson had originally proposed a sharp reduction in the number of foreign-born professional workers allowed into the country (see Nature, 378, 117; 1995). His bill also called for a two-year waiting period before non-US graduate students could be hired by a US employer. It eliminated the category of 'outstanding researcher' under which scientists and engineers could be exempted from a long certification process, and imposed a fee on employers who wanted to hire non-Americans.

All these provisions have now been stripped from the proposed legislation. A frustrated Simpson, acknowledging the intense pressure on the committee from business interests such as the computer company Microsoft, which want to retain the option of employing foreign-born programmers, said last week that he would remove "every shred" of employment-based restrictions from his bill.

Lamar Smith (Republican, Texas) has already made similar concessions in amending his complementary immigration bill in the House of Representatives, which will be merged with the Senate bill before coming to a vote, probably within the next couple of months.

Although immigration has surfaced as a potentially volatile issue in the current presidential campaign, it cuts across party political lines, with Democrats and Republicans taking part on both sides of the debate. Almost three-quarters of Americans said in a recent poll that they favour tighter immigration laws. But businesses and universities have been especially vocal in protesting against additional restrictions on hiring foreignborn talent.

A recent meeting between Simpson and the chief executives of 50 US companies failed to defuse this opposition, which has thus left him no choice but to remove the planned restrictions, according to Senate staff.

Tony Reichhardt

\section{Chemists sound warning on sponsorship of exhibitions}

Washington. The American Chemical Society (ACS) has broken off talks with the Smithsonian Institution about revising the Science in American Life exhibition, ending the hopes of critics that the controversial show would be revised with a more 'proscience' perspective.

In an article in this week's issue of the ACS publication Chemical and Engineering News, the society will go public with its criticisms of the exhibition for the first time. It will also warn other potential donors against sponsoring exhibitions at the Smithsonian if they want to retain any control over the result.

The ACS pulled out of the talks - which were initiated a year ago by Michael Heyman, the secretary of the Smithsonian - after concluding that they were not going to lead to the changes it was seeking.

According to ACS officials, the last straw came in December, when the Smithsonian offered the society a list of 35 changes it would make, and asked for $\$ 400,000$ to make them, on top of the $\$ 5.3$ million that the ACS had already paid to mount the exhibition. The ACS rejected the offer and abandoned the talks.

The Science in American Life exhibition has come under criticism from scientists and others because of its emphasis on arguments about intellectual property rights and its stark portrayal of the development of the atomic bomb. Its defenders argue that the exhibition breaks new ground by assessing science's relationship with society, rather than simply trumpeting its achievements.

"We've been working with the Smithsonian at great length, and we feel we've reached an impasse," says Joan Shields, a professor of chemistry at the Long Island University, New York, and chairwoman of the ACS. "Every time we meet with the directors of the Smithsonian, they seem to agree that change is needed, but either they don't know how to do it, or they won't do it."

Shields says that the ACS had been working consistently behind the scenes to change the exhibition, both before and after its opening in April 1994, and was only now going public about its concerns. The exhibition, she says, is "a litany of revisionist history" which draws attention to "social injustice and environmental catastrophe" without balancing them against the achievements of science.

The exhibition will continue to run permanently at the National Museum of American History on the Mall in Washing- ton DC, with sponsorship attributed to the ACS. No changes to its original content are expected. "We are out of the picture now," says Shields. "It is unlikely that the Smithsonian will do anything, now that we're not knocking on their door."

Shields added that she thought the society's 150,000 members would understand both its original decision to spend money on the exhibition while ceding control over its contents, and its recent decision to stop negotiations over changes. "We had a goal in mind," she says, including better public understanding of science, and attracting young people into careers in science and

IMAGE
UNAVAILABLE
FOR COPYRIGHT
REASONS

chemistry. "We thought it would be achieved, but it hasn't been."

The American Physical Society (APS) which had no role in sponsoring the exhibition - publicly attacked it soon after its opening, leading Heyman to promise "some changes which will render the exhibition a lot more balanced" (see Nature 374, 207; 1995). But Bob Park, head of public affairs at APS, said that nothing had since been done to the exhibition. The matter is expected to be raised by the APS Council at its general meeting in St Louis, Missouri, next week.

The Smithsonian has produced its own hundred-page assessment of the exhibition, based on a survey of 400 visitors. It found that "the visiting public entered the exhibition with a very positive view of science and technology, and that their views were reinforced and confirmed, rather than changed in either a positive or negative direction".

The ACS provided the funding for Science in American Life. But, as the sponsor, it had no more editorial control over the selection of the material exhibited than any other private company sponsoring a cultural event. In February last year the Smithsonian promised to consult the visiting public, the ACS and other interested parties before implementing changes to the exhibition.

Colin Macilwain 